\title{
Digital Political Public Relations Strategy Basuki T. Purnama - Djarot S. Hidayat on Twitter in the 2017 Regional Election of Jakarta (Study Case of Ethnicity and Religion Issue)
}

\author{
$1^{\mathrm{st} *}$ Edoardo Irfan \\ Dept. Communication Science \\ Al Azhar University of Indonesia \\ Jakarta, Indonesia \\ edoardo_irfan@uai.ac.id
}

\author{
$2^{\text {nd }}$ Burhan Agung Swastiko \\ Dept. Communication Science \\ Al Azhar University of Indonesia \\ Jakarta, Indonesia \\ burhanswastiko@gmail.com
}

\begin{abstract}
At this time, digital political public relations is already a crucial factor. In the digital political public relations, the management function as an enabler to purposeful communicating and action is paramount, because digital communication should not happen in a void. In public relations the understanding that relationships are central to successfully maintaining reputation, support, and a level of influence. One of the ways better realized through digital political public relations than other embodiments of the practice. Utilize the advantages of digital platforms with using social media such as Twitter. Public relations politics team Basuki T. Purnama - Djarot $S$. Hidayat candidates trying to maintain public reputation and support in the 2017 Regional Election of Jakarta. Because, the issue of ethnicity and religion which was attached to the candidates. The content or political message, and those called as influencers had become important variables in handling the issue. The research questions in this writing are, what was the form of the contents? How was the role of influencers during the campaign? The result of this research shows that the content or political message and the influencer had formed the image of this candidate as the "diversity" persons. In the key message of diversity, the image of Basuki T. Purnama - Djarot S. Hidayat was built as the servant of the people that work for all circles in Jakarta. It was formed in order of differentiation with the other candidate. Nevertheless, this political message of diversity was too late to be delivered explicity, and getting more intensified when the campaign was entering its second round. This demonstrate that there is a management void in digital communication by their public relations team.
\end{abstract}

Keywords- Political public relations, Social Media, Influencer, Content/political message

\section{INTRODUCTION}

Digital political public relations is already a crucial factor, and will become even more important in the future. The next phase will involve moving beyond the campaign context to examine how citizens use and are impacted by digital political messages on a daily basis. This type of ongoing political discourse is important to public relations practitioners if they are to understand the history and context of the issues, and will enable a longer lasting relationship with publics. Strategically, this involves several different opportunities for political public relations, many of which harken back to the definition of political public relations outlined earlier by Stromback and
Kiousis. Recall their explication of political public relations as being:

The management process by which an organization or individual for political purposes, through purposeful communication and action, seeks to influence and to establish, build, and maintain beneficial relationships and reputations with its key publics to help support its mission and achieve its goals." [1]

Now consider two foci of this definition in relation to digital political public relations. First, the management function as an enabler to purposeful communicating and action is paramount, because digital communication should not happen in a void. Digital dissemination is yet another tool for communicating the message, and it should be done in complete alignment with other efforts. If digital is only regarded as usable at lower levels within the organization, then the entire communication strategy is in jeopardy if communication eff orts contradict the message or if inappropriate levels of attention are given to one of the organizational issues. The management function ensures that communication, including digital communication, is congruent and prioritized according to the overall strategy.

Second, the understanding that relationships are central to successfully maintaining reputation, support, and a level of influence is perhaps better realized through digital political public relations than other embodiments of the practice. Considering this, digital political public relations face the greatest opportunity through integrating relationship building into specific strategies. Digital tools can be employed for the purpose of influence and persuasion efforts, but in order to achieve such goals, the recipient has to be attuned to the source and content.

Inevitably, in digital public relations requires digital media that is integrated into every proactive marketing strategy, long before the public relations program is approved and implemented. When socialized media is applied to communication programs, it provides us with a basis that unites awareness, the right combination, and the application of technology to increase human interaction without obstacles and aims for relationships that produce results. This application must be supported by social platforms and people 
who use it, provide a channel for people to communicate, create a community for interaction, and ultimately facilitate interaction. The application is social media.

The study of public relations and the public where people participated is important in any communication program. Of course in digital public relations, it requires integration into any proactive marketing strategy, long before it is planned and implemented. When socialized media is applied to communication programs, the media gives us a foundation that unites awareness, proper involvement, and technology application to enhance human interaction without any obsctruction and lead to meaningful relationships. This application must be supported by social platforms and people who use it, offer channels for people to communicate, create communities for interaction, and ultimately influence behavior. The application is social media.

Social Media is changing the PR outreach paradigm from pitching to personalized and genuine engagement. PR must now influence the new influencers as well as traditional media and analysts and to do so, much work must be done before conversations ever start.

Through social media networking sites, communication made through online media no longer runs in the same direction (from sender to receiver) but develops into two directions (sender - sender) and even multi-directional (receiver). The development of site trends on microblogs such as those on Twitter opens up new opportunities for organizations to communicate and foster relationships with various stakeholders or the public. According to Julie Uldam and Anne Vestergaard, social media has encouraged institutions in the community to have access to a wider scope of society. Access is used by the community to form conversations related to any issues [2].

Power of social media to influence the public are based exclusively on its social aspect: this means interaction and participation that can ve developed through campaign. Social media, as part of the new media, is considered to be the liaison between the various components of society. This media is considered to have changed the way the candidates in campaigning. Looking back, Norris has described that there are at least three periods of evolution from the campaign itself: pre-modern (the middle of 19th century to 1950s); the modern (the early 1960s to the late 1950s); and post-modern (post1990s). The pre-modern campaign is still local and the media used is limited to radio, pamphlets, and the supporting press. In its development, the campaign has become modern, with a national scope, where television has become part of conventional media every day. The latter is a post-modern campaign, in which Internet networking is an important instrument. This goes hand in hand with conventional media that have existed previously like television, which is also still used in the era of post-modern campaigns [3].

In Indonesia, political campaigns using social media are nothing new. The 2009 presidential election can be regarded as a political moment that is colored by the utilization of social media as a means of political communication of the candidates. Not only during the presidential election, the use of social media in the political campaign also occurred in the 2012 Regional Election of Jakarta. In this election, almost all candidates and campaign team utilized social media in campaigning. Similarly, during 2017's Regional Election of
Jakarta, not only through conventional media, this election was also utilizing new media, where there were social media in it. In its implementation, Regional General Election Commission Jakarta had created and socialized campaign procedures that can be performed by each candidate, including those related to campaigns in social media. In the document of campaign procedures, Regional General Election Commission Jakarta required registration of social media accounts used by candidates, to be subsequently submitted to Regional General Election Commission Jakarta, Election Supervisory Agency Jakarta, and Indonesian Police [4].

Nowdays, various topics of conversation can be found on social media, including politics. In social media Twitter, for example, topics related to government policy are often in the spotlight, especially if the policy creates a polemic of pros and cons in society. The debate that occurs among Twitter users (netizen) is commonly referred to as the term 'twitwar'. The 2017 Regional Election of Jakarta was also inseparable from this twitwar phenomenon. One of the issues was related to ethnicity and religion. The issue of ethnicity and religion was a picture that the problem of identity becomes very crucial and quite dominate throughout this regional election. The candidate, Basuki T. Purnama - Djarot S. Hidayat are the candidates who are exposed to the issue. Basuki T. Purnama (Ahok) was a subject of conversation related to ethnicity and religion issues, even before the 2017 Regional Election campaign period of Jakarta Capital City took place.

Judging further a bit, ethnicity and religion issues had hit Ahok since received a rejection from the Islamic Defenders Front (FPI) as he was about to be appointed as Governor of Jakarta, replacing Joko Widodo. The reason for the FPI's for the rejection was Ahok's religion and behavior [5]. The issue of religion in the form of "do not choose non-Muslim leaders" still attacking the couple Ahok - Djarot during the 2017 Regional Election of Jakarta took place. Dictionaries who call "Ahok kafir" were also commonly found in social media. In addition to religion, the use of diction which mentioned Ahok and certain ethnic also inserted, as "China". This issue of ethnicity and religion had attacked candidate Ahok - Djarot since the first round of campaign period. In its development, the issue that hit the candidate pair was not only about the duty of choosing a Muslim leader. "Al-Maidah: 51" was considered to be a crucial point in the development of ethnic and religious issues. Some believe that "Al Maidah: 51" was a momentum for some people to attack Ahok, related to his speech during a working visit in Kepulauan Seribu on September 27, 2016.

The issue of ethnicity and religion that became a topic of political battle during elections Jakarta 2017 certainly had a chance to influence the electability of Ahok - Djarot. Issues that tended to have a negative sentiment towards this candidate pairs deserve to be anticipated, even neutralized. Specifically, a campaign strategy was needed in order to deal with these negative issues. A Strategy is a set of planning and management in order to achieve certain goals. To achieve this goal, the strategy is not only a roadmap to know the details of a system but also shows how the tips to be delivered so that the operational tactics of a system can go according to the original plan [6]. Furthermore, its own campaign strategy includes both prevention and handling of an issue that has the potential to have negative sentiments toward individuals and institutions. In this case, the campaign team and volunteers of Ahok - Djarot also implemented the strategy, one of them in 
facing the ethnic and religious issue that appeared in social media. The goal itself is to minimize the impact of negative issues.

In elections Jakarta 2017, social media such as Twitter had been chosen by all candidates, including Ahok - Djarot during the campaign or political socialization. Furthermore, political content or messages rolled through Twitter social media were crucial to watch for. The message should carry the intent and purpose of the candidate, whose goal is to harmonize the political intentions. Not just about content or messages, about who is talking (communicator) also has an important role. In a process of campaigning, not only candidates run the role, but people who are usually members of the campaign team or volunteers also have this role. In social media, such as Twitter, are those who are called as influencers or KOL (Key Opinion Leader) who run the role. It is these influential people who will conduct interpersonal communication, disseminating political information, which may influence the political decisions of those who follow it [7]. Related to this, Ahok Djarot and the campaign team also coordinated with dozens of volunteers who can be said as Twitter influencers. During the campaigning process, these people assisted them in political persuasions, such as neutralizing negative issues about ethnicity and religion. From the problems described above, then there are some research questions that the author made reference namely the content or political messages such as what did Ahok - Djarot and the campaign team use in the campaign strategy, especially related to the issues of ethnicity and religion? And how was the role of influencers in implementing the Ahok - Djarot campaign strategy related to ethnicity and religion issues on Twitter?

\section{LITERATURE REVIEW}

\section{A. Patterns of Utilization of the Internet and Social Media in Political Campaigns}

One of the closest activities with political communication is the campaign. The campaign is a conscious, gradual and sustainable process that is carried out over a period of time with the aim of influencing a predetermined target audience [8]. When campaigning, every political actor brings certain issues that should be of interest to the public. The development of today's campaigns that use the internet and new media as its instruments certainly has characteristics. These characteristics cannot be separated from the characteristics of the new media itself. Bas W. van Doorn describes some of the characteristics of new media, namely: 1) New media have larger variations in terms of content, both in terms of breadth (number of topics) as well as in-depth (amount of information about topics raised); 2) New media provides unlimited control to its users (user) for the information received. Users have more ability to select and sort the source of news they want to know [9].

These characteristics are reinforced by the exposure of Julie Uldam and Anne Vestergaard, that social media has encouraged agencies in the community to have access to a wider scope of society.

Referring to the above characteristics, the utilization of new media, especially social media in political campaigns can give some advantages when compared to conventional media. These advantages include more content that can be generated, broader target coverage or political goals, to a faster marketing process. Not only that, social media also does not close the possibility will suppress greater spending when compared with marketing through conventional media. Utilization of social media in a political campaign has its own pattern.

Ahmad and Popa form a pattern of exploiting the internet and social media in the context of political marketing, by adapting the previously created patterns - Listen, Engage, Create, Share \& Integrate - by Getting The Message Out: Social Media Daily Activity Plan, and the pattern previously arranged by Lilleker et al in Informing, Engaging, Mobilising, or Interacting: Searching for a European Model of Web Campaigning. From the combined pattern above, it can be seen that the internet and social media can be utilized as a tool or media to listen, bind, create political messages, integrate and share, persuade value and information brought by political parties and candidates to the constituents. Through the internet and social media, political messages such as promoting candidates and political parties can be repeated over and over, in addition to the mobilization and interaction with netizens or audiences [10].

When it is expanded in a more specific way, it can be seen that there are 4 general stages, such as Listen, Engage, Create, and Share and integrate, which will continue to have repeating patterns associated with social media activation itself. Listen, is a monitoring stage related to what other people talked about and the news that appeared related to the candidate. Furthermore, Engage, is an attempt to attract more netizens' involvement in candidate-related topics. Create, is the stage of creating content - the use of certain tags is suggested to capture more netizens [11]. Content that has been made in the end enter the stages of Share and integrate, which applies a wider spread. The result going back again in the first stage - where the candidate re-entered the Listen stage, in order to monitor what was pre- campaigned. The above pattern applies to the implementation of social media campaigns conducted in general.

\section{RESUlt AND Discussion}

\section{A. Positive Campaign on Social Media Platform - Twitter}

Content created by the campaign team of Ahok - Djarot was always integrated with each other across all social media channels used. Therefore, we can find the same post content on Twitter, Instagram, or Facebook that is used as an official campaign channel. Through social media Twitter, the campaign team run a positive or supportive campaign containing various content on the performance that had been done during the previous administration; vision, mission, and work program that carried; up to personal branding issues related to Ahok and Djarot itself. The material posted was also various shapes, there were pictures such as photos or infographics, some are video. Visual materials such as pictures and videos were considered to attract more impression and engagement from netizens.

Content related to performance and work programs being promoted became a topic that had dominated during the first round campaign. Based on the interview with one of the Communication Team of Rumah Lembang, Arief Bungaran Sitohang, that the political messages which were conveyed through social media in this round were related to the handling of citizen's problem (interview on November 10, 2017). Specifically, Ahok - Djarot wanted to show the superiority as 
a candidate who had started development for Jakarta and had a measured concept and work program compared to other candidates. At the same time, this performance-related political message also aimed to show the repositioning of Ahok who was a hard worker, and not a religious defender. This was related to the issue of religious defamation that had emerged since the early days of the election campaign. Therefore, the sentiments that arise against Ahok - Djarot were very diverse, as they came from a variety of content - not just about the performance and the programs that were carried.

Utilization of social media Twitter for socialization or political campaigns, started from Ahok's personal account, @ basuki_btp at the end of October 2016. In addition, there was also an official campaign account used, namely @ AhokDjarot. The posted content was related to the activity of 'blusukan'. On social media, Ahok - Djarot always underlined that blusukan activities are not intended to promote themselves or gather votes but to check the condition of citizens.

Other positive content that was often socialized by Ahok - Djarot was \#PatunganYuk and \#KampanyeRakyat. Claimed as the first people's fundraising for the campaign, the \#PatunganYuk and \#KampanyeRakyat campaigns aimed to invite the public to participate in campaign financing donations during the election of Jakarta take place. These \#PatunganYuk and \#KampanyeRakyat campaigns were echoed as a form of Ahok - Djarot commitment, that they were the servants of the citizens of Jakarta and would do their best for the citizens. Other campaigning moments such as the election debate also served as an arena for them to show the track record and work program being carried. In the process, during the election debate, social media like Twitter also worked. The official account @ AhokDjarot did a livetweet during the debate. During the first round of election of Jakarta, three official debates were held by General Election Commission Jakarta on January 13, January 27, and February 10,2017 . This was also applied when the final debate was held in the second round on April 12, 2017.

Entering the second round, the campaign team intensified a more varied positive campaign compared to the previous round. For example, campaigns or socialization around the track record and work program packed in political messages with \#JakartaPunyaSemua hashtag. Through this tagline and hashtag, Ahok - Djarot wanted to deliver diversity messages to netizen. In the Instagram account, @ AhokDjarot (March 21, 2017), the meaning of the tagline \#JakartaPunyaSemua was described as follows: First, Jakarta has all levels of society. From religion, race, and any group may live in Jakarta; and Second, Jakarta has all the supporting facilities so that all citizens can live prosperously. In addition, positive campaigns were also manifested in various contents that showed Ahok - Djarot in millennial activities with the title "Ahok Show". In this activity Ahok - Djarot dug a variety of questions from netizens, to then be answered by the candidate pair.

The positive contents of the political messages outlined above always went hand in hand with the neutralization efforts on negative issues that attacked Ahok - Djarot, both in the context of candidate pairs and individuals. Negative issues related to the track record and the program being carried, certainly appear. So when we look further, we can see that 'twitwar' often happened between Ahok - Djarot supporters with those who were against. No exception to the issue of ethnicity and religion.

Other neutralization attempts could be seen from a number of content or hashtag wars popping up in the timeline. For example, the appearance of Islamic Defense Action (Aksi Bela Islam) on November 4, 2016, which was also marked by the emergence of the \#AksiDamai411 hashtag. To compensate for this, the Ahok volunteers co-sponsored the \#LoeDemoGueKerja hashtag. The hashtag had a political message that the 411 Action was an action that politicized religion [12].

The efforts to neutralize the negative sentiments of the ethnicity or religious defamation issues, not only rely on negative campaigns such as content warfare above. The positive campaign also became the foundation to always socialize good things related to Ahok - Dajrot. Positive campaigns conducted in the first round more highlight on the track record and work program carried by Ahok - Djarot. The content that contained the political message not only played a role to highlight the advantages of Ahok - Djarot in terms of experiences and achievements that had been achieved but simultaneously also had been an attempt to dampen the issue or content that called Ahok a religious blasphemer. Entering the campaign period of the second round, visible political messages were more likely lead to the concept of diversity or diversity with the \#JakartaPunyaSemua hashtag. Contentrelated themes of diversity were more common. In fact, for positive campaigns around the work program that was carried was also wrapped with a message of diversity.

From all the above description can be underlined that campaigns that run on social media such as Twitter were running an integrated inter-type campaign. Positive and negative campaigns always went hand in hand. The merged accounts were not only the official account of the campaign, but there were also other accounts that moved to participate in campaigning Ahok - Djarot during the regional election took place.

\section{B. Strategy of Using Influencers in Handling Ethnicity and Religion Issues}

Social media volunteerism in the Ahok - Djarot campaign during the 2017 Regional Election of Jakarta was shown by the activities of a number of influencers in their social media in providing support to the candidates. Influencers are those who have a strong influence on social media and are usually proven by a large number of followers. The influencers of Ahok - Djarot supporters themselves came from various backgrounds, such as artists, musicians, and politicians. The integrated and massive involvement of these influencers adds impressions and engagement to the positively related content of the candidates in the end. Not to mention when the influencers not only post the content in question but also when they had a conversation on social media with other accounts, which of course could continue to stream the conversation with key messages or political messages that are brought.

A number of influencers active on Twitter social media that supported Ahok - Djarot, among them were Guntur Romli (@GunRomli), UlinYusron (@ulinyusron), Addie MS (@addiems), and Renny Fernandez (@ RennyFernandez). The influencers played a role to convey things about the 
performance that had been done by the incumbent. Not only that, they and other influencers also enlivened the offline activities held during the campaign period, such as activities at RumahLembang or at the "KonserGue2" (known as \#KonserGue2) held on February 4, 2017. In social media activation daily, the influencers usually focus on the particular issues brought. For example, Renny Fernandez (@RennyFernandez), a film and advertising director, who made performance socialization videos and feature videos about people who had been helped by Ahok's policy [13]. Other artists, as well as influencers who supported Ahok Djarot, were Addie MS. He was one of the influencers of musicians who were active on social media as supporters of Ahok - Djarot. Through Twitter account, he once whistled that no artist or musician was paid to support Ahok. The political moment that Addie encouraged to support Ahok was to hold a choir at the city hall in Jakarta on May 10, 2017, as a form of support for Ahok who was detained for a religious blasphemy case [14]. This shows that the influencers of Ahok - Djarot supporters had not only talked about the performance or track record of Ahok - Djarot while leading Jakarta but also in the case of blasphemy that dragged Ahok. This had been clarified in the previous discussion that the message of diversity or diversity ultimately became the focus of a key message or a political message built and propagated to supporters. This political message certainly not only stopped at the (official) campaign team but also continues to be coordinated and disseminated to supporters.

Such coordination was shared by other influencers, Ulin Yusron or@ulinyusron, a journalist and is known as one of the founders of news portal BeritaSatu.com. Ulin stated that coordination was an important thing, to determine the topics, angles, and hashtags for campaign. This was due to volunteer social media activism or volunteers, where there was no command in it. This kind of work was done in conveying any political message, whether it was a positive campaign related to performance socialization or track record and diversity, or even negative campaigns did. Including what related to the handling of ethnicity and religion issues, such as AlMaidah:51.

Choosing a frontal position in defense of Ahok related cases of blasphemy was chosen by some influencers. Others preferred in a more general context, by spreading political messages of diversity or diversity. This is in accordance with the key message or political message to be echoed in the second round, where diversity or diversity becomes an urgency in itself. Through \#JakartaPunyaSemua hashtag, the political message was disseminated by influencers and other social media volunteers. On the one hand, the message was still circling around the government policies, on the other hand, this message also talked about the diversity of Jakarta. Nevertheless, the support provided was still within the same content umbrella, which stemmed from the political message that Ahok - Djarot was a candidate partner who upheld tolerance. For the influencers, Ahok had been the victim of the politicization of religion, which ultimately also became the victim of criminalization of the law. As stated by UlinYusron, that Ahok had mastered all competencies, programs, and integrity - without the issue of religious politicization, political opponents had no deadly ammunition [15].

Seeing the above description can be concluded that the influencer had become a communicator in conveying all matters relating to the prospective incumbent, not only in terms of work programs that carried but also about the image of Ahok - Djarot (branding). Inviting influencers to talk about Ahok - Djarot, even in the context of volunteering, shows that the use of social media, such as Twitter to convey political messages, does have a broader and more powerful reach. The influencers with follower characteristics are expected to be one of the links between the prospective incumbent, with the public exposed to social media every day.

\section{CONCLUSION}

There are at least two important variables highlighted in relation to the social media campaign strategy undertaken in the face of ethnic and religious issues emerging. Firstly, it is necessary to see the formation of political content or messages to be conveyed to the public. Secondly, the role of the influencers on Twitter in promoting Ahok - Djarot. Both of these need to be reviewed in terms of how to deal with the ethnicity and religion issues described above.

Content is an important part of a digital-based campaign. The term "content is a king", indicates that creating interesting and informative content can attract the attention of netizens (awareness). In political campaigns, the content in question contains a political message that aims, starting from delivering the offered program, to the image of the candidates. With regard to Ahok - Djarot, content created during the two-round campaign is divided into 2 messages, which are related to the track record until the first round of work programs manifested with a number of tags \#BadjaTerbukti, one of them proved, and related to diversity or diversity in the second round - realized with the \#JakartaPunyaSemua tagline. Specifically, Ahok - Djarot wanted to show the superiority as a candidate who had started development for Jakarta and had a measured concept and work program compared to other candidates. At the same time, this performance-related political message also aimed to show the repositioning of Ahok who was a hard worker, and not a religious defender. This was related to the issue of religious defamation that had emerged since the early days of the election campaign.

The second point is the influencer. Influencer becomes another important variable. The influencers who are members of the Ahok - Djarot. With diverse backgrounds, such as artists, professionals, social media activists. They are coordinate each other to voice Ahok - Djarot's political messages to followers or followers. The content or twitwar wars of Twitter are due to the role of these influencers through coordination, they post certain content or messages, for which the content or message continues to be disseminated by influencers and other netizens. This often leads to 'friction' with other parties, who also post controversial content or messages.

The most interesting part of the implementation of the Ahok - Djarot campaign strategy in dealing with the ethnicity and religion issue is that, since the beginning of the campaign, the effort to neutralize this issue has never been the main key message of all political content or messages carried. The efforts made are still partial, both in terms of the content being rolled out, as well as in terms of influencers who are vocal in conducting campaigns in this regard. Issues around performance and track record were the main choices rolled out by the political public relations team at the beginning of the campaign - with the intention of inviting netizens to look at 
what Ahok - Djarot offered rationally. In other words, the message that is carried is to keep netizens away from the emotional side, such as those related to issues of religious background, ethnicity, and others. The issue of pluralism or diversity through the hashtag \#JakartaPunyaSemua, which was rolled out tighter in the second round, was felt to be too late to be socialized through an social media campaign. Intensification timing of content or political message in this case is very important. This relates in efforts to "answer" the issue of ethnicity and religion which has negative sentiments towards Ahok - Djarot since the beginning of the campaign period. This shows that there is a management vacuum in the digital communication of their political public relations team.

Content and influencers have become two important variables that cannot be separated in the context of political campaigns on social media, such as Twitter. Both are related to each other and can be utilized in socialization and political marketing though. Furthermore, it needs to be seen thoroughly whether the campaign strategy carried out can be concluded as a successful one or not. This matter certainly depends on the main objective of the campaign itself. For example, in neutralizing the ethnicity and religion issue at a certain period, what it does is by rolling out a rival hashtag, and the campaign objectives to be achieved are how much impressions and engagement are generated; or it can also be seen from the distribution of overall conversation sentiment during the campaign period. This will specifically see which sentiment dominates. When viewed from this objective, the online campaign carried out by the winning team and influencers for Ahok - Djarot on social media can be said to be successful. Aside from the high impressions and engagement aspects, as well as the dominance of positive sentiment that was generated due to the influencers who were part of the AhokDjarot volunteer team, the diverse content also encouraged this to be realized. However, this certainly cannot lead to conclusions related to the final results of the election itself. Apart having to see and analyze other variables, in terms of campaign implementation it also needs to be seen as a whole, both in terms of online campaign performance (social media) and ground campaigns. the overall issues that arise in the timeline (not only from the ethnicity and religion issue), and analyze other variables, in terms of the implementation of the campaign also needs to be viewed as a whole, both from the performance of social media campaigns and ground campaigns carried out.

\section{ACKNOWLEDGMENT}

Big thanks to LP2M Al Azhar University of Indonesia.

\section{REFERENCES}

[1] Stromback, Jesper and Kiousis, Spiro, "Political Public Relations: Principles and Applications", New York: Routledge, 2011, pp. 38.

[2] Stromback, Jesper and Kiousis, Spiro, "Political Public Relations: Principles and Applications”, New York: Routledge, 2011, pp. 153.

[3] Uldam, Julie Uldam and Anne Vestergaard, "Civic Engagement and Social Media: Political Participation Beyond Protest”. London: Palgrave Macmillan, 2015.

[4] Jakarta General Elections Commission, "Keputusan KPU Provinsi Jakarta Nomor 58/Kpts/KPU-Prov-010/Tahun 2016 Tentang Pedoman Teknis Pelaksanaan Kampanye Pemilihan Gubernur dan Wakil Gubernur", Jakarta, 2017

[5] Merdeka.com, "FPI Tolak Ahok Jadi Gubernur Karena Bukan Islam \& Bacotnya Busuk", https://www.merdeka.com/peristiwa/fpi-tolakahok-jadi-gubernur-karena-bukan-islam-bacotnya-busuk.html, September 24, 2014.

[6] Effendy, Onong Uchjana, "Komunikasi Teori dan Praktek", Jakarta: Grasindo, 1992, pp. 29.

[7] Nimmo, Dan, "Komunikasi Politik: Komunikator, Pesan, dan Media", Tjun Surjaman, Translator, Bandung: PT. Remaja Rosdakarya, 2005.

[8] Venus, Antar, "Manajemen Kampanye: Panduan Teoritis dan Praktis dalam Mengefektifkan Kampanye Komunikasi”, Bandung: Simbiosa Rekatama Media, 2007, pp.7.

[9] Van Doorn, Bas W, "Media dan Politik", dalam John T. Ishiyama \& Marijke Breuning, Bandung: Simbiosa Rekatama Media, 2013, pp. 1145 .

[10] Ahmad, Nyarwi Ahmad and Ioan-Lucian Popa, "The Social Media Usage and the Transformation of Political Marketing and Campaigning of the Emerging Democracy in Indonesia: Case Study of the 2012 Gubernatorial Election of the Special Region of the Capital City Jakarta", in Bogdan Patrut \& Monica Patrut (ed.), "Social Media in Politics”, New York: Springer International Publishing, 2014, pp.106.

[11] Adi, Ana and Darren G. Lilleker, "Getting The Message Out: Social Media Daily Activity Plan", UK: The Creative Enterprise Bureau, The Media School, Bournemouth University, 2012.

[12] In-depth interview with Andrino, Wibi, Romli, Guntur, Sitohang, Arief Bungaran, Yusron, Ulin Ni'am, Jakarta, May 1, 2018.

[13] Herbawati, Neneng dan Aditya Sani, “Ahok di Mata Mereka”, Jakarta: Kompas Gramedia, 2017, pp. 386.

[14] Tribunnews.com, "Addie MS Pimpin Paduan Suara di Balai Kota, Aksi Mereka Mengharukan", http://www.tribunnews.com/metropolitan/2017/05/10/addie-mspimpin-paduan-suara-di-balai-kota-aksi-mereka-mengharukan, May 10, 2017.

[15] In-depth interview with Andrino, Wibi, Romli, Guntur, Sitohang, Arief Bungaran, Yusron, Ulin Ni'am, Jakarta, May 1, 2018. 